\title{
Research and Application of Anti-floating Schemes of Deep Foundation Pit of Subway for Underwater Excavation and underwater concrete sealing
}

\author{
Sheng Luo ${ }^{1}$ \\ ${ }^{1}$ Ranken Railway Construction Group Co., Ltd., Chengdu, Sichuan, 610045, China
}

\begin{abstract}
To implement deep foundation pit of subway construction with underground continuous wall adopting underwater excavation and waterproofing concrete bottom sealing curtain, the depth of bottom concrete must first meet the anti-floating requirements of the foundation pit. Since the elevation of the bottom slab of the station is certain, the thicker the sealing concrete, the deeper the excavation depth of the foundation pit, the greater the buoyancy of the water to be withstood, and eventually the thicker the sealing concrete, so the selection of foundation pit anti-floating scheme is very critical. This paper combines the practical construction of the deep foundation pit of the main structure of Yongdingmenwai station which is in the third phase of Beijing Metro Line 8 construction project, and analyzes and compares the anti-floating scheme of the foundation pit, so as to select a more reasonable anti-floating scheme, in order to apply experiences for future similar projects and construction.
\end{abstract}

\section{Introduction}

With the rapid development of urban rail transit, more and more multiple-line interchange stations result in the fact that the excavation depth of the subway foundation pit are getting deeper and deeper, and even some subway pits have a depth of more than $30 \mathrm{~m}$. However, for the deep foundation pit of subway with high underground water level and no effective water-proof layer at the bottom of the pit in the ultra-thick and strong water-permeable sand and pebble layer, if the conventional dewatering scheme outside the pit is adopted for groundwater treatment, the huge displacement is not conducive to the protection of groundwater resources. also, the surrounding municipal pipe network may not have such drainage capacity. If the underground continuous wall is combined with the base grouting to reinforce the water-stop scheme, the base is in the dense pebble layer, so the water-stop effect of reinforcement is difficult to be guaranteed, both the construction period and cost are both difficult to be controlled. For the deep foundation pit of subway in complex hydrogeological environment, conventional water treatment measures cannot effectively control the groundwater level. At present, a groundwater treatment scheme combining underground continuous wall with underwater excavation and underwater concrete bottom sealing is proposed in the field of metro, which successfully solves the problem of groundwater control in the deep foundation pit of metro in the thick and strongly permeable sand and pebble layer.

This article introduces the construction project of Yondingmenwai station site as the practical example of the groundwater treatment scheme which adopts underground continuous wall combining underwater excavation and underwater concrete bottom sealing. Through analyzing and comparing the anti-floating schemes for subway deep foundation pit, the optimal thickness of the concrete bottom sealing is determined. with this scheme implemented, groundwater will be effectively isolated, furthermore to ensure the safety of the construction of foundation pit.

\section{The overview of construction project}

Yongdingmenwai station is the transfer station of Beijing subway line 8 , line 3 and line 14. It is located in the south of the intersection of yongdingmenwai street and Jinghu railway, and in the north of the intersection of shazikou of yongdingmenwai street. The station is parallel to Yongdingmenwai street, located at the west side of Yongdingmenwai street side road and under the sidewalk. The station is an underground frame structure with four floors and three spans. The main structure of the station is constructed by cut and cover method. The total length of the station is $139.2 \mathrm{~m}$, the width of the regular section is $24.7 \mathrm{~m}$, the buried depth of the base slab of the station is $31.4 \mathrm{~m}$, and the expansion section of shield method is $33.9 \mathrm{~m}$.

Due to the specific geological and hydrological condition on this site, a groundwater treatment scheme that adopts underground continuous wall combining underwater excavation and underwater concrete bottom sealing has been selected among 3 alternatives where the others include dewatering method and underground continuous wall with grout curtain method. 
To successfully implement underwater continuous wall combining base sealing concrete method, there are 2 key points need to be investigated and settled. The first issue is whether the groundwater will be effectively isolated. Failing to isolate groundwater might cause the foundation pit base float while construction. The second key point is to determine the optimal thickness of base sealing concrete which leads to the reduction of depth of excavation. Considering earlier mentioned issues, there are several anti-floating methods, such as uplift piles, weighted concrete and shear resisting grooves on underwater continuous wall with bottom sealing concrete have been discussed and analyzed.

\section{Introduction of underwater base concrete sealing method}

The construction process of underwater continuous wall combing base sealing concrete method is firstly building underwater continuous wall as exterior protected construction, then excavating desiccatedly to design underground water level with bracing structure implemented simultaneously, finally excavating underwater to the bottom of the foundation pit. According to previous structural analysis, the thickness of base sealing concrete of foundation pit for Yongdingmenwai station site is 1.2 meters. Because the sealing concrete grouting underwater needs to bear great water pressure in advanced stage, it is required that the sealing concrete has adequate strength and water tightness. However, the massive underwater concrete construction casting has high requirements on construction organization, concrete properties and construction technology. In order to ensure the feasibility of this project, the grout curtain will be implemented partly. The foundation pit is divided into 16 partitions. The main foundation pit is separated by $1 \mathrm{~m}$ thick separating wall. The maximum dimension of the partition is $14.0 \mathrm{~m} \times 15.3 \mathrm{~m}$ (for shield tunnel section), while the minimum dimension is $16.5 \mathrm{~m} \times 11.9 \mathrm{~m}$. the detailed partitions is demonstrated in figure below

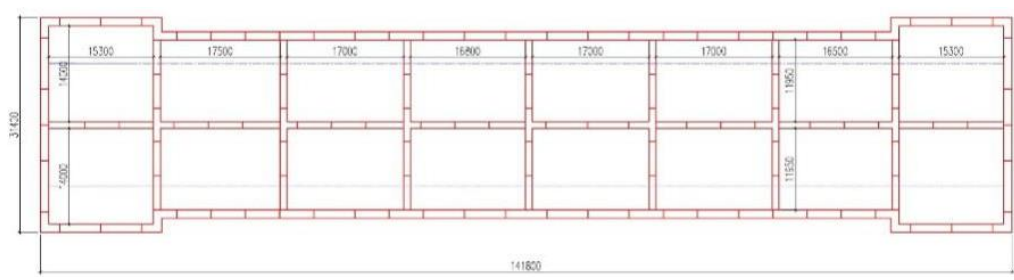

Figure 1 the layout of partitions arrangement in Yondingmenwai station site

\section{Anti-floating method analyzing and comparing}

Since the elevation of the station bottom plate is determined, the thicker the concrete is, the deeper the excavation of the foundation pit will be. The base slab is located in the dense pebble 7 layer which results in relatively high difficulty for underwater excavation. In order to save the construction period and cost, the depth of underwater excavation should be minimized. Through calculation and analysis, if the self-weight of conventional concrete is used to bear the buoyancy of groundwater, the thickness of the base sealing concrete should be $9.5 \mathrm{~m}$ thick, and the depth of underwater excavation of the foundation pit will be as deep as $22.1 \mathrm{~m}$, and the supporting structure is difficult to build in this range, so it needs to be optimized and reduced. Combined with the actual situation and construction conditions at the site, after a number of demonstrations, the thickness of the concrete was chosen to be $4 \mathrm{~m}$. The bottom of the concrete to the bottom of the foundation pit is reserved for $0.5 \mathrm{~m}$ as a gravel layer to lay the blind pipe to eliminate the water seepage which may occur in the middle of the underground continuous wall frame and the interface and the base sealing concrete. According to the size of the pit partitions, the maximum size of the partition in the regular section is $17.5 \mathrm{~m} \times 11.95 \mathrm{~m}$, and the maximum size in the shield tunneling section is $15.3 \mathrm{~m} \times 14 \mathrm{~m}$. the calculation of concrete self-weight is illustrated in chart below.

Chart 1. Base sealing concrete self-weight anti-floating (for each partition)

\begin{tabular}{|c|c|c|c|c|c|c|c|}
\hline $\begin{array}{l}\text { Anti-floating } \\
\text { calculation }\end{array}$ & $\begin{array}{c}\text { Concrete } \\
\text { density } \\
\left(\mathrm{KN} / \mathrm{m}^{3}\right)\end{array}$ & $\begin{array}{l}\text { Base sealing } \\
\text { concrete } \\
\text { self-weight } \\
(\mathrm{KN})\end{array}$ & $\begin{array}{l}\text { Anti-floating } \\
\text { depth } \\
\text { (m) }\end{array}$ & $\begin{array}{c}\text { buoyancy } \\
(\mathrm{KN})\end{array}$ & $\begin{array}{c}\text { Calculation } \\
\text { safety } \\
\text { coefficient }\end{array}$ & \multicolumn{2}{|c|}{ Code requirement } \\
\hline $\begin{array}{c}\text { Self- } \\
\text { weight/buoyancy }\end{array}$ & 23 & 19239.5 & 15.224 & 31837.19 & 0.604 & 1.05 & $\begin{array}{c}\text { Not } \\
\text { satisfied }\end{array}$ \\
\hline
\end{tabular}

According to the above calculation, the conventional underwater sealing concrete weight cannot meet the antifloating requirements, so additional anti-floating measures should be considered. These measures mainly include: (1) setting up uplift piles at the bottom of base sealing concrete; (2) increasing the self-weight of the base sealing concrete, using counterweight concrete; (3) adopting base sealing concrete and the underground continuous wall with shear resisting grooves simultaneously to prevent floating. 


\subsection{Anti-lifting analysis of uplift pile and base sealing concrete}

According to the calculation, the conventional underwater sealing concrete cannot meet the anti-floating requirements. If the uplift pile and the base sealing concrete are used together to resist the floating, the antifloat force of the uplift pile of each partition needs to be computed. The calculation process of anti-floating force is:

For regular section: $F_{B}=31837.19 \times 1.15-$ $19239.5=17373.27 \mathrm{kN}$
According to the geological situation, the soil layer below the sealing concrete is respectively pebble layer $(7$, fine sand layer(9) 3 , pebble layer(9). In order to shorten the length of the uplift pile, the diameter of the uplift pile is taken as $1 \mathrm{~m}$, and the lateral resistance is enhanced by constructing uplift pile post-grouting. According to the Technical Code for Building Pile Foundations, the postgrouting resistance enhancement coefficient of the pebble layer is taken as 3 , and the post-grouting resistance enhancement coefficient of the fine sand layer is taken as 2 .

Chart 2. Uplift resistance force on each uplift pile for regular section

\begin{tabular}{|c|c|c|c|c|c|c|}
\hline Soil layer & thickness(m) & $\begin{array}{c}\text { Pile } \\
\text { diameter(m) }\end{array}$ & $\begin{array}{c}\text { Security coefficient } \\
\text { of pull strength }\end{array}$ & $\begin{array}{c}\text { Maximum lateral } \\
\text { pressure(kPa) }\end{array}$ & $\begin{array}{c}\text { Enhancement } \\
\text { coefficient }\end{array}$ & $\begin{array}{c}\text { Uplift resistance } \\
\text { force(including self- } \\
\text { weight)(kN) }\end{array}$ \\
\hline Pebble(7) & 3.3 & 1 & 0.5 & 150 & 3 & 1205.19 \\
\hline $\begin{array}{c}\text { Silty-fine } \\
\text { sand(9) }\end{array}$ & 1.1 & 1 & 0.5 & 70 & 2 & 133.91 \\
\hline pebble(9) & 12.2 & 1 & 0.5 & 150 & 3 & 4455.56 \\
\hline total & 16.6 & $/$ & $/$ & $/$ & $/$ & 5794.67 \\
\hline
\end{tabular}

According to previous calculation, for regular section, 3 piles with a diameter of $1 \mathrm{~m}$ and a length of $16.6 \mathrm{~m}$ in each partition is adequate to fulfill the anti-float requirement.

$F_{\text {uplift }}=3 \times 5794.67=17384.00 \mathrm{kN}>$ $17373.27 \mathrm{kN}$, fulfill the requirement.

\subsection{The anti-float analysis of base sealing counter weight concrete}

In order to meet the requirements of anti-buoyancy of foundation pit, the weight of sealing concrete can be increased. The counterweight concrete is a new type of concrete produced by professional grinding of mineral materials and high quality chemical additives whose unit weight can reach 25 55 $(\mathrm{KN} / \mathrm{m} 3)$.

Chart 3. Anti-floating calculation of bottom-sealing concrete (each partition)

\begin{tabular}{|c|c|c|c|c|c|c|c|}
\hline Location & Anti-floating calculation & $\begin{array}{c}\text { Unit } \\
\text { weight } \\
\left(\mathrm{kN} / \mathrm{m}^{3}\right)\end{array}$ & $\begin{array}{c}\text { Self-weight of } \\
\text { bottom-sealing } \\
\text { concrete }(\mathrm{kN})\end{array}$ & $\begin{array}{c}\text { Water level of } \\
\text { anti-floating } \\
(\mathrm{m})\end{array}$ & $\begin{array}{c}\text { Buoyancy } \\
(\mathrm{kN})\end{array}$ & $\begin{array}{c}\text { Safety factor } \\
\text { in calculation }\end{array}$ & $\begin{array}{c}\text { Codes and regulations } \\
\text { requirement }\end{array}$ \\
\hline $\begin{array}{c}\text { Regular } \\
\text { section }\end{array}$ & Self-weight/buoyancy & 40 & 33460 & 15.224 & 31837.19 & 1.051 & 1.05 \\
\hline
\end{tabular}

According to the calculation, the bottom-sealing concrete is made of counterweight concrete, and the weight of counterweight concrete required for the standard section is $40 \mathrm{kN} / \mathrm{m} 3$, Due to the bottom sealing concrete of each bin needs to be poured under water simultaneously, when the bottom sealing concrete adopts counterweight concrete, the quantity of concrete carriage trucks will significantly be increased which results in the increased difficulty in on-site construction management. Meanwhile, high unit weight concrete is made of high unit weight materials such as slag and iron sand which are likely to rust in underwater environment. Hence this construction scheme is not appropriate for this construction.

\subsection{The anti-floating analysis of underwater continuous walls with shear resisting grooves}

There are two shear resisting grooves implemented between bottom sealing concrete and underwater continuous walls for each partition. The dimension of groove is $500 \mathrm{~mm}$ in height and $200 \mathrm{~mm}$ in depth, while the center spacing of the 2 grooves is $1500 \mathrm{~mm}$. Shear resisting grooves allow the bottom sealing concrete and underwater continuous walls can be treated as one component in antifloating mechanical calculation. the elevation of underground water level is $19 \mathrm{~m}$, and the elevation of foundation pit bottom in the regular section is $8.276 \mathrm{~m}$, The unit weight of water is $10 \mathrm{KN} / \mathrm{m} 3$, and the unit weight of plain concrete is $23 \mathrm{KN} / \mathrm{m} 3$. The thickness of enclosure wall is assigned as $1.2 \mathrm{~m}$ and the thickness of partition separating wall is assigned as $0.5 \mathrm{~m}$ due to difference of structural stiffness of surrounding diaphragm wall and the strength reduction of partition walls caused by shear resisting grooves. Hence, the 3D simulation model of bottom sealing concrete's anti-floating analysis can be generated by midas Gen. detailed calculations are demonstrated followingly:

Regular section: $F_{\text {buoyancy }}=10 \times(19-8.276+$ 4.5) $=152.24 \mathrm{kN} / \mathrm{m}^{2}$

1) The internal force computation for regular section $(17.5 \mathrm{~m} \times 11.95 \mathrm{~m})$ : 
According to modeling computation result, the unit maximum required shear is $486 \mathrm{kN} / \mathrm{m}$ and maximum unit bending moment on unit slab is $1260.3 \mathrm{kN} \cdot \mathrm{m}$.

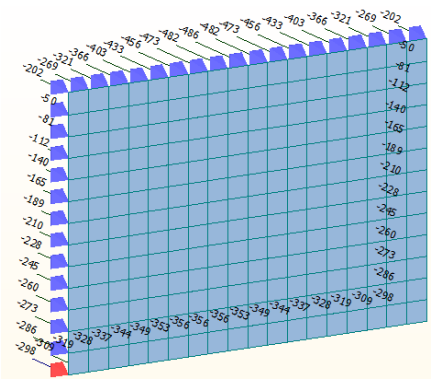

Figure 2. Counter force diagram of regular section $(17.5 \times$ $11.95 \mathrm{~m})$

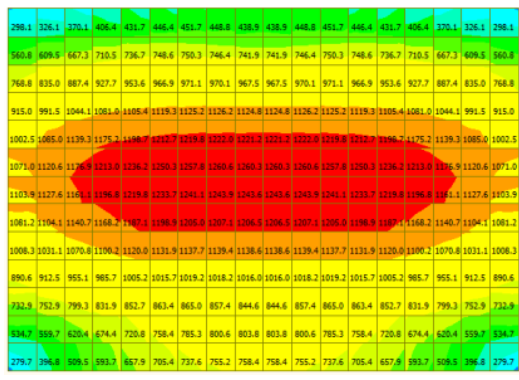

Figure 3. bending diagram of regular section $(17.5 \times 11.95 \mathrm{~m})$

a) Checking calculation for shear resisting grooves

According to Specification for Design of Concrete Structure (GBJ10-89), shear bearing capacity oblique section should fulfill:

$$
\begin{gathered}
\mathrm{V} \leqslant 0.7 \times \beta_{\mathrm{h}} \times \mathrm{ft} \times \mathrm{b} \times \mathrm{h}_{0} \quad \beta_{\mathrm{h}}=\left(800 / \mathrm{h}_{0}\right)^{0.25} \\
\mathrm{~V}=0.7 \times \beta_{\mathrm{h}} \times \mathrm{f}_{\mathrm{t}} \times \mathrm{b} \times \mathrm{h}_{0}=0.7 \times(800 / 1000) \quad 0.25 \times 1.57 \\
\times 1000 \times 1000 / 1000=1039.37 \mathrm{KN} / \mathrm{m} \\
\mathrm{V}>1.25 \times 486=607.5 \mathrm{KN} / \mathrm{m}
\end{gathered}
$$

Meet the requirement.

b) Checking calculation for bending capacity of plain concrete

According to Specification for Design of Concrete Structure (GBJ10-89) appendix D3.1 bending capacity of plain concrete bending component:

$$
\begin{gathered}
M>1260.3 \times 1.25=1575.4 \mathrm{kN} \cdot \mathrm{m} / \mathrm{m} \\
M \leq \gamma \times f_{c k} \times b \times h^{2} \\
=1.201 \times 2.2 \times 0.55 \times 1000 \\
\times \frac{\frac{4000}{6}}{1000000}=3876.03 \mathrm{kN}
\end{gathered}
$$

2) Pulling resistance analysis of underwater continuous walls

The interface shear stress between underwater continuous walls and bottom sealing concrete is provided by the pulling resisting force of underwater continuous walls (including self weight and side friction). The detailed calculation will be demonstrated following:

a) Regular section $(17.5 \times 11.95 \mathrm{~m})$ :

According to modeling computation result, the unit maximum required shear is $486 \mathrm{kN} / \mathrm{m}$ and maximum unit bending moment on unit slab is $1260.3 \mathrm{kN} \cdot \mathrm{m}$.

Self-weight of retaining walls:

$\mathrm{F}_{\text {retaing }}=(25-10) \times(10.724+4.5+7.5)+25 \times(31.4-$

$$
10.724)=857.8 \mathrm{KN} / \mathrm{m}>486 \times 1.15=558.9 \mathrm{KN} / \mathrm{m}
$$

Whose provided interface shear stress meets the requirement.

Self-weight of partition walls:

$$
\begin{gathered}
F_{\text {partition }}=(25-10) \times 7.5=112.5 \mathrm{KN}<356 \times \\
1.15=409.4 \mathrm{KN} / \mathrm{m}
\end{gathered}
$$

The interface shear stress requirement provided by partition walls fails to meet the requirement; hence the side friction of partition walls should be considered in calculation.

Chart 4. Side friction resistance calculation of partition walls in regular seciton (unit meter)

\begin{tabular}{|c|c|c|c|c|c|}
\hline Soil layer & $\begin{array}{c}\text { Thickness } \\
(\mathrm{m})\end{array}$ & $\begin{array}{c}\text { Calculated } \\
\text { length }(\mathrm{m})\end{array}$ & $\begin{array}{c}\text { Pulling } \\
\text { resistance } \\
\text { coefficient }\end{array}$ & $\begin{array}{c}\text { Limit side } \\
\text { resistance } \\
(\mathrm{KPa})\end{array}$ & $\begin{array}{c}\text { Pulling } \\
\text { resistance } \\
(\mathrm{KN})\end{array}$ \\
\hline pebble(7) & 3.3 & 1 & 0.5 & 150 & 247.5 \\
\hline $\begin{array}{c}\text { Silty-fine } \\
\text { sand (9) }\end{array}$ & 1.1 & 1 & 0.5 & 70 & 38.5 \\
\hline Pebble 9) & 3.1 & 1 & 0.5 & 150 & 232.5 \\
\hline sum & 7.5 & $/$ & $/$ & $/$ & 518.5 \\
\hline
\end{tabular}

$\mathrm{F}_{\text {partition }}+\mathrm{F}_{\text {side resistance }}=112.5+518.5=631 \mathrm{KN} / \mathrm{m}>356$ $\times 1.15=409.4 \mathrm{KN} / \mathrm{m}$, The interface shear stress requirement is fulfilled.

The feasibility of the schemes that the underwater continuous walls and bottom sealing concrete could be treated as one mechanical component due to the adoption of a pair of shear resisting grooves is verified by previous calculation. This Scheme's biggest advantages are using the water-dividing curtain as far as possible, and treating underwater continuous walls and bottom sealing concrete as one mechanical component. To be more specific, this scheme requires no other anti-floating measures which can save both financial and time expenses, also can reduce scale of on-site construction process hence facilitate to better construction organization. On the other hand, shear resisting groove is an effective tool in waterproofing, which also can reduce the possibility of water seepage. However, the construction quality of shear resisting grooves will remarkably influence the anti-floating performance of the foundation pit, hence the routine cleanup of the shear resisting grooves shall be guaranteed in subsequent construction and operation.

\section{Conclusion}

At this point, we have provided several schemes can be 
adopted in future similar constructions. Selection among these schemes should be based on specific situations. Our recommendations including:

1. The scheme which combines underwater continuous walls and bottom sealing concrete is likely to be restricted by the construction environment and conditions of underwater pouring concrete. To use this kind of scheme, the optimized scheme with adoption of shear resisting grooves is recommended. It has three main advantages:

a) The anti-floating performance will be increased due to shear resisting grooves combining retaining walls and partition walls with bottom sealing concrete as an anti-floating component.

b) Both cost and time duration of construction can be reduced.

c) Shear resisting grooves also facilitates to restrict water seepage.

It should be noted that adopting shear resisting grooves requires regular cleanup of grooves in order to ensure the performance of shear resisting grooves.

2. Counterweight concrete scheme requires appropriate selection of compounding which proportion of different ingredients should be determined on field tests. In order to reduce the unit weight of counterweight concrete, structural grooves with varied depths can be installed between walls and bottom sealing concrete. This measure will increase the interface friction coefficient hence reduce the contribution of heavier counterweight concrete's self-weight.
3. For uplift piles with bottom sealing concrete scheme, considering the difficulty of pore formation in dense sand-pebble layers, it can be applied in sand-pebble layers whose compactness is low. Surrounding shear resisting steel plate is a decent option to ensure the strength of the joints between uplift piles and concrete.

\section{References:}

1. Sun, Zhiyong. (2016) Application of Underwater Excavation Method in Municipal Excavation Engineering $[\mathrm{J}]$ Urban Mass Transit, v.19; No.162(03). DOI: CNKI: SUN: GDJT.0.2016-03-028

2. Yu, Y., Li, Z., \& Wei, M. (2007). Research on groundwater control technology of deep foundation pit. [J] Ground Water, 29(003), 36-38. doi: CNKI: SUN: DXSU.0.2007-03-013.

3. CECS137-2002, (2003). Specification for Structural Design of Reinforced Concrete Sinking Well of Water Supply and Sewerage Engineering [S]. Beijing: China Architecture \& Building Press.

4. GB50010-2010, (2015). Code for design of concrete structures [S]. Beijing: China Architecture \& Building Press.

5. Wei Jianwen, "Study on Internal Force and Deformation of Deep Foundation Pit Support Structure of Subway", Shanxi Architecture, 2018(13). 